\title{
DETERMINANTS OF HOUSEHOLD'S FOOD AND NUTRITION SECURITY IN INDONESIA
}

\author{
FAKTOR PENENTU KETAHANAN PANGAN RUMAH TANGGA DI INDONESIA
}

\author{
Esta Lestari and Jiwa Sarana \\ Pusat Penelitian Ekonomi - LIPI, Economic Research Center, Indonesian Institute of Sciences \\ esta.lestari@gmail.com, saranajiwa@yahoo.com
}

\begin{abstract}
Indonesia has experienced a significant improvement in its status of food security, yet it is not followed by improvement in nutritional security. Number of regions with food insecurity decreased significantly however problems of malnutrition among children such as stunting rate peaked for above $37 \%$ and obesity rate for just below $20 \%$; known as double-burden malnutrition. This study aimed to examine factors affecting the nutritional security for households in Indonesia by incorporating food and non-food data. Cross sectional regression model is employed from SUSENAS 2013 in which households' food security is proxy by calorie intakes as a function of households' expenditures, mother's age, mother's education, dummy of closet types, number of member in households, and dummy of access to clean water. The results showed that several variables are positively affects households' dietary intake namely expenditure, mother's age, and mother's education. Moreover, the other variables are negatively and significantly affect food consumptions namely type of closet, number of family member and type of clean water. The result implies that the government need to take significant strategies and program to address problems of nutrition by conducting two strategies, 1) changes in household food consumption pattern through shifted mindset and perception of parents 'from knowledge (especially mothers') in healthy food consumption, 2) improving infrastructure and access for clean water, sanitation, and social security to broaden access of poor for better health status.
\end{abstract}

Keywords: Food and Nutrition Security, households'calorie intakes, malnutrition.

JEL Classification: I150, Q180, I380

\begin{abstract}
Abstrak
Indonesia telah mengalami perbaikan signifikan dalam status ketahanan pangan namun sayangnya hal ini tidak diikuti oleh perbaikan dalam capaian kerahana gizi. Jumlah wilayah dengan kerentanan pangan semakin sedikit terutama di wilayah timur Indonesia sepert Nusa Tenggara Timur dan Papua, namun permasalahan malnutrisi anak justru meningkat termasuk di wilayah barat, dimana secara total stunting di Indonesia mencapai lebih dari $30 \%$ dan tingkat obesitas hampir $20 \%$, atau dikenal sebagai beban ganda malnutrisi. Studi ini bertujuan untuk menganalisis berbagai faktor yang mempengaruhi ketahanana pangan rumah tangga di Indonesia dengan mengkombinasikan data pangan dan non pangan. Metode regresi data silang (cross section) digunakan untuk data SUSENAS tahun 2013 dimana ketahanan pangan rumah tangga diproksikan dengan asupan kalori sebagai fungsi dari pengeluaran, usia ibu, pendidikan ibu, dummy jenis kloset, jumlah anggota rumah tangga, dan dummy akses air bersih. Hasil studi ini menunjukkan bahwa beberapa variabel berpengaruh secara positif terhadap asupan ketahanan pangan rumah tangga, meliputi tingkat pengeluaran, usia ibu, dan pendidikan ibu. Sebaliknya, variabel yang berdampak negatif mencakup jenis kloset, jumlah anggota rumah tangga, dan akses terhadap air bersih. Implikasi dari hasil ini adalah pemerintah perlu mengambil langkah strategis untuk mengatasi permasalahan malnutrisi, meliputi 1) perubahan pola konsumsi melalui perubahan cara pandang dan persepsi terhadap pangan sehat terutama kepada ibu;2) memperbaiki infrastruktur dan akses terhadap air bersih, sanitasi dan jaminan sosial yang dapat memperluas akses kelompok miskin pada perbaikan status kesehatan.

Kata kunci: ketahanan pangan dan gizi, asupan pangan rumah tangga, malnutrisi.

Klasifikasi JEL: I150, Q180, I380
\end{abstract}




\section{INTRODUCTION}

Food and nutrition are important dimensions towards sustainable livelihood and is reflected in the Sustainable Development Goals (SDGs). The inclusion of nutritional aspects addressing the challenges of hunger and malnutrition worldwide is not only agenda in developing countries but also in developed ones by 2030 . However, the fact that increasing number of malnutrition happened amid surplus for food indicating paradox of food security, meaning that food security alone does not assure improvement in nutritional achievement (Global Hunger Index, 2015). Food security has a limited effect on nutritional wellbeing of individuals, unless other measures are taking into account such as social infrastructure (Iram and Butt, 2004). Therefore, addressing malnutrition need to integrate food and nutrition security in which are both are channeled by access and utilization dimensions of food security.

Despite the fact that Indonesia experience improvement in its food security, prevalence of mulnutrition is increasing. One of three children in Indonesia is stunted, account for almost 9 million kids of total (Ministry of Health, 2013). Households' food insecurity is contributed by many variables, not only food but also non-food ones that affect food intakes for all the member. In terms of food consumption, Indonesians' food consumption patterns have been disarray from healthy food diet as shown by unbalanced-calorie and -protein intakes heavily emphasized on high calorie of foods. This is mainly due to a large consumption of rice, flour, oil and fat as well as processed food - Meanwhile, expenditure pattern displays heavily spending on specific items especially tobacco and processed food account for $6 \%$ and $12.6 \%$, respectively. Compared to expenditure for rice $(6.83 \%)$, Fish $(6.83 \%)$ and Meat (1.93\%), spending on tobacco and processed food are far above the basic necessities (Figure 3) (BPS, 2014). Indonesia ranked the second as the worlds' most imported countries after Egypt account for 9.1 million tons (2015/2016) (World Atlas, 2018) As the results is a sluggish increase in diversity dietary score (Pola Pangan Harapan/PPH
) of 88 far below the national target of 100 (2017) (Badan Ketahanan Pangan, 2017)

Meanwhile, several non-food indicators were showing improvement. BPS (2015) reported improvement of health infrastructurerelated to nutrition, especially sanitation and drinking water. Between 2000 and 2015, sanitation coverage in Indonesia increased by almost $90 \%$ from $32.7 \%$ to $62 \%$ of total households, as well as drinking water at the same rate from $37.5 \%$ to $71 \%$. Combination of food and non-food aspects in Indonesia still have a little impact on nutritional achievement. As a middle income country, its nutrition security is comparable to low income countries. Stunting rate peaked to $37,2 \%$ along with obesity rate for roughly $12 \%$, indicating a double-burden malnutrition (Figure 1) (Ministry of Health, 2010). The more crucial problem is increasing rate of wasting especially mild underweight among children or known as hidden hunger (Ministry of Health, 2013). This study is aimed to investigate variables affecting food and nutrition security in households' level by incorporating not only food but also non-food input variables to bridging food and nutrition security by employing data SUSENAS 2013.

\section{LITERATURE REVIEW}

\section{Food and Nutrition Security}

Concept of food and nutrition security transformed along with the dimension and definition, in order to answer the challanges on hunger and malnutrition. Originally, the concept of Nutrition security goes beyond food alone (Benson, 2008). It also concerns on the environmental aspects such as sanitary environment, adequate health services and knowledgeable care to ensure a healthy life of a household and its member. Individual nutrition security is manifested in nutritional status related both to diet and health. Meanwhile, nutrition security and nutrition status linked by the food security.

The framework of nutrition security rooted from determinants of nutritional status (UNICEF, 1990). Malnutrition is contributed by two factors namely internal and external factors. The basic cause is mainly influenced by external factors, such as socio-economic 


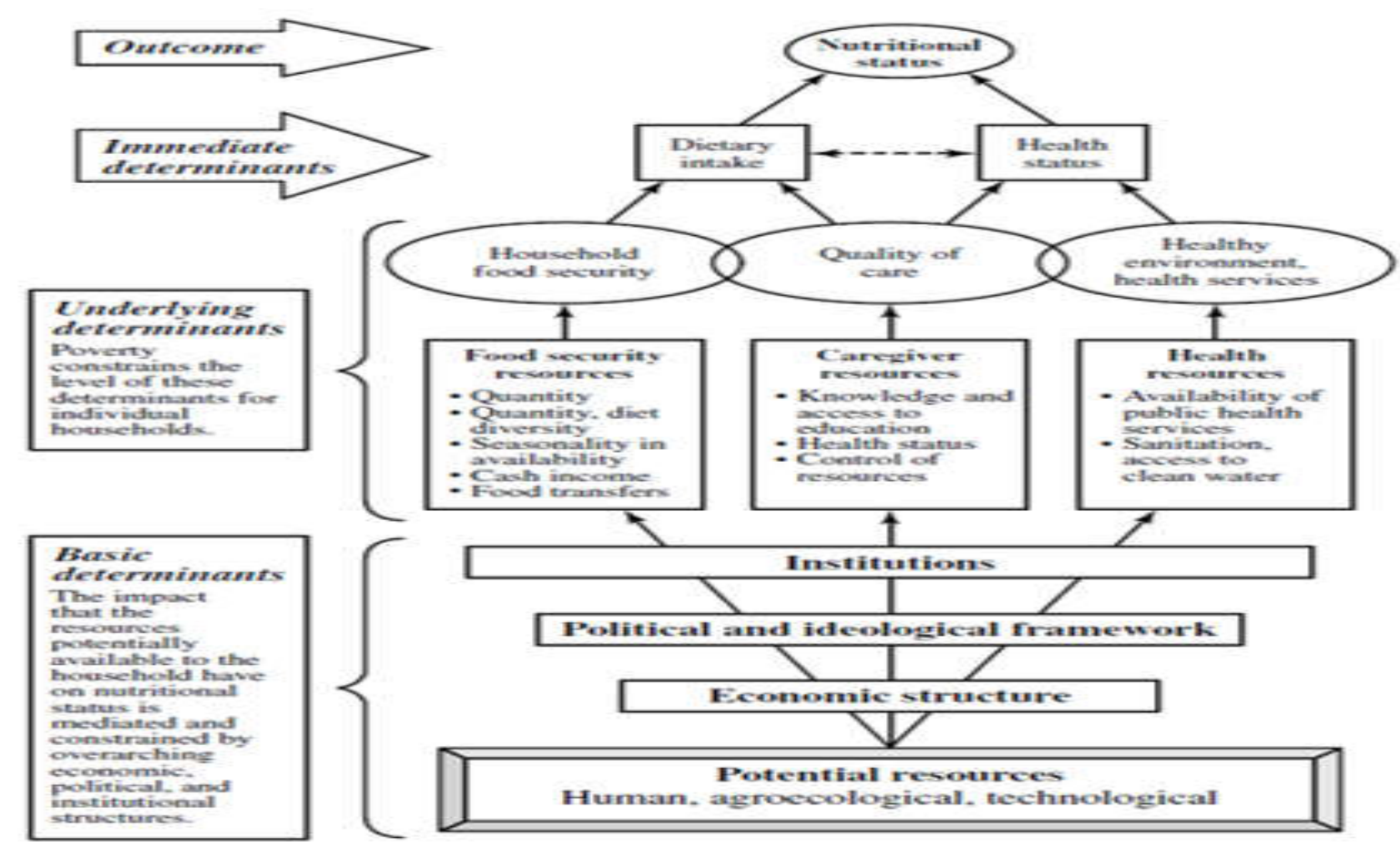

Figure 1. Conceptual framework of the determinants of nutritional status

Source: Adonted from IJNICFF (1990) in Rohertson 2003

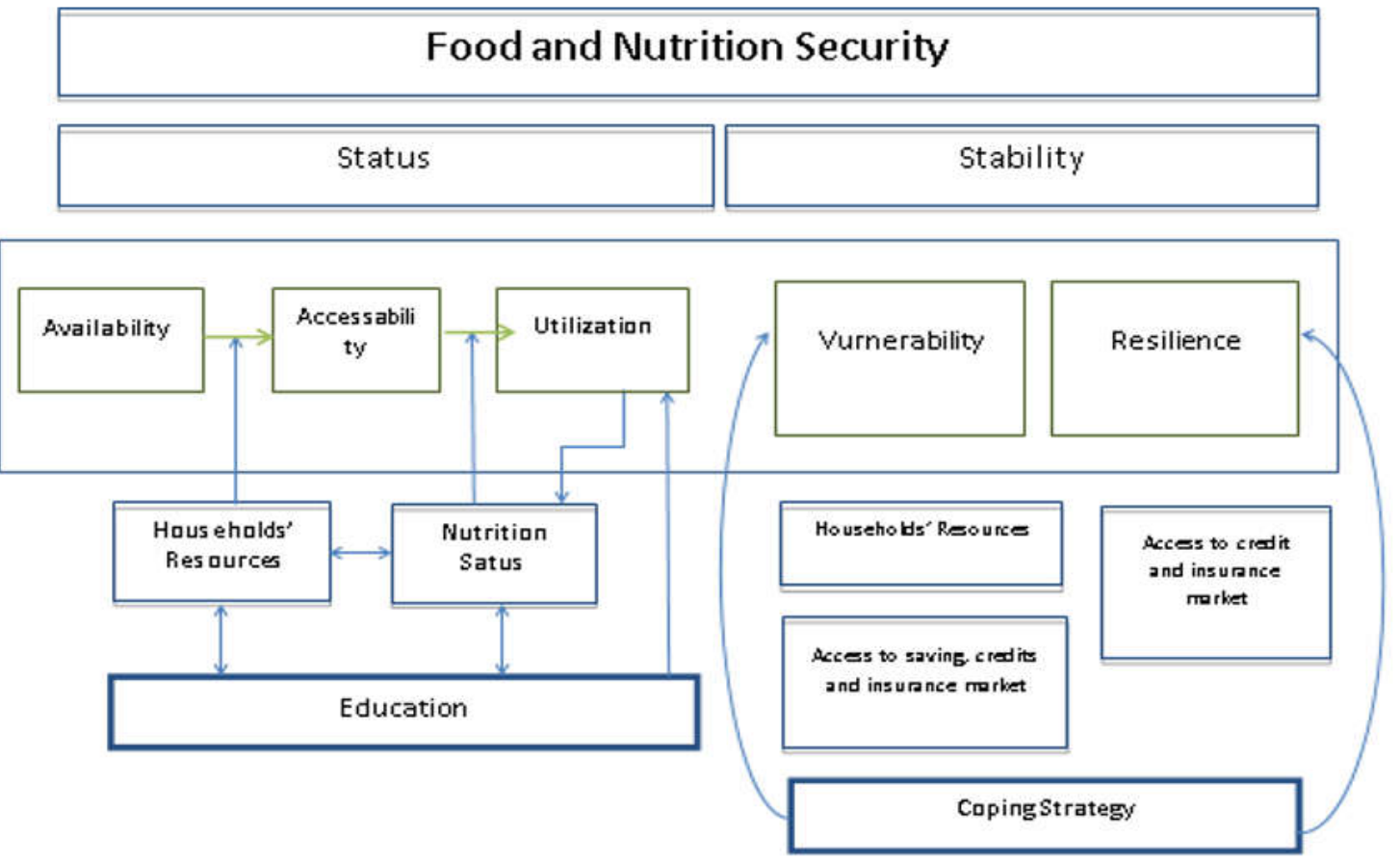

Figure 3. Conceptual Framework of Food and Nutrition Security

Source: Adopted from Pieters et, al. (2013)

and political situation that prevent poor people to have access towards capital. These conditions resulted in economic disadvantage lead to poverty and insecurity in various aspects characterized by inability to generate income and accumulate capital that constraint the poor to acquire access to health services and good sanitation. Readily available food, appropriate health systems and a "healthy" environment are ineffective unless these resources are used effectively. As a result, the absence of proper care in households and communities is the third necessary element of the underlying causes of malnutrition. 


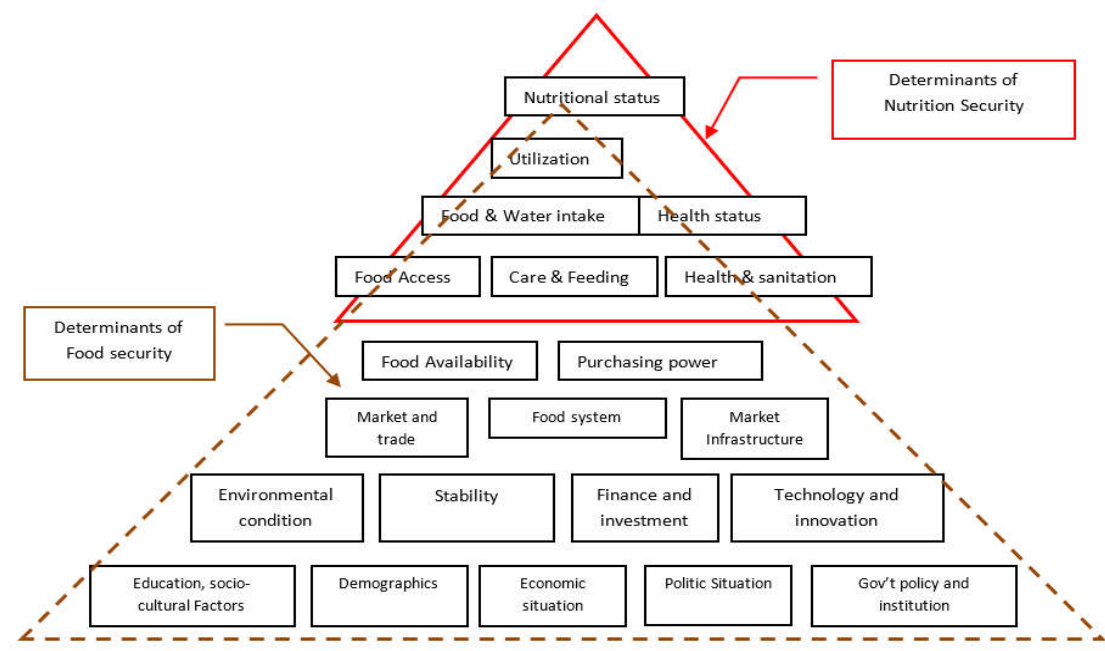

Figure 2. Integration between nutrition and food security pillars

Source: FAO in CAPSA (2015)

The concept of food security has been developed in pararel with the nutrition concept. They were not incorporated each other until in 1980-s, along with raising of the human right issues to address adequate food and nutrition called for committed national governments to play a more proactive role in the 2000s as part of poverty reduction and the achievement of Millennium Development Goals.

Food security as a concept initiated in the World Foood Summit Food in 1974. At first, this concept developed to address problems of unstable food supplies and prices on the world market resulted to food security insurance schemes, which assured international access to physical food supplies. While in 1980s, following the success of the green revolution which helped to increase food production (food availability), it was recognized that global hunger were not caused shortfalls in food supplies but rather the decline of purchasing power of specific social groups, therefore, the dimension was broadened to include both physical and economic access to food supply. In 2000, the dimension of food utilization was added to address challenge of human right to have adequate food and nutrition. Therefore, food and nutrition security integrate both concepts of malnutrition and food security (Weingartner, 2000).

Food security itself has four dimensions, consist of availability, access, utilization and stability. Of four dimensions, nutrition is channeled by access and utilization dimensions along with other components that built nutrition security.

The two most commonly used conceptual frameworks show significant differences. The food security framework emphasizes an economic approach in which food as a commodity as a central focus. The malnutrition framework adopts a biological approach in which the human being is the starting point. However, both frameworks promote an interdisciplinary approach to ensuring food and nutrition security. Both acknowledge that food alone is not sufficient to secure a sustainable satisfactory nutritional status and, therefore, aspects of health must be considered.

Moreover, non-food aspects related to nutrition needs a complex interaction as improvement in access to food is not sufficient to improve nutritional status if it is not followed by improvement of access to non-food inputs such as quality health care facilities and services, education, sanitation, and clan water or ineffective mechanism for delivering these services, or known as "leaking bucket effect" (Butt, 2004). Consequently, greater concern should be placed on improving access to these non-food inputs (USDA, 1998; Pinstrup-Anderson, 2000).

Malnutrition is mainly influenced by dietary intake as a necessary condition of food security even though it is not sufficient condition (Tiwari, Skoufias, \& Sherpa 2013). 


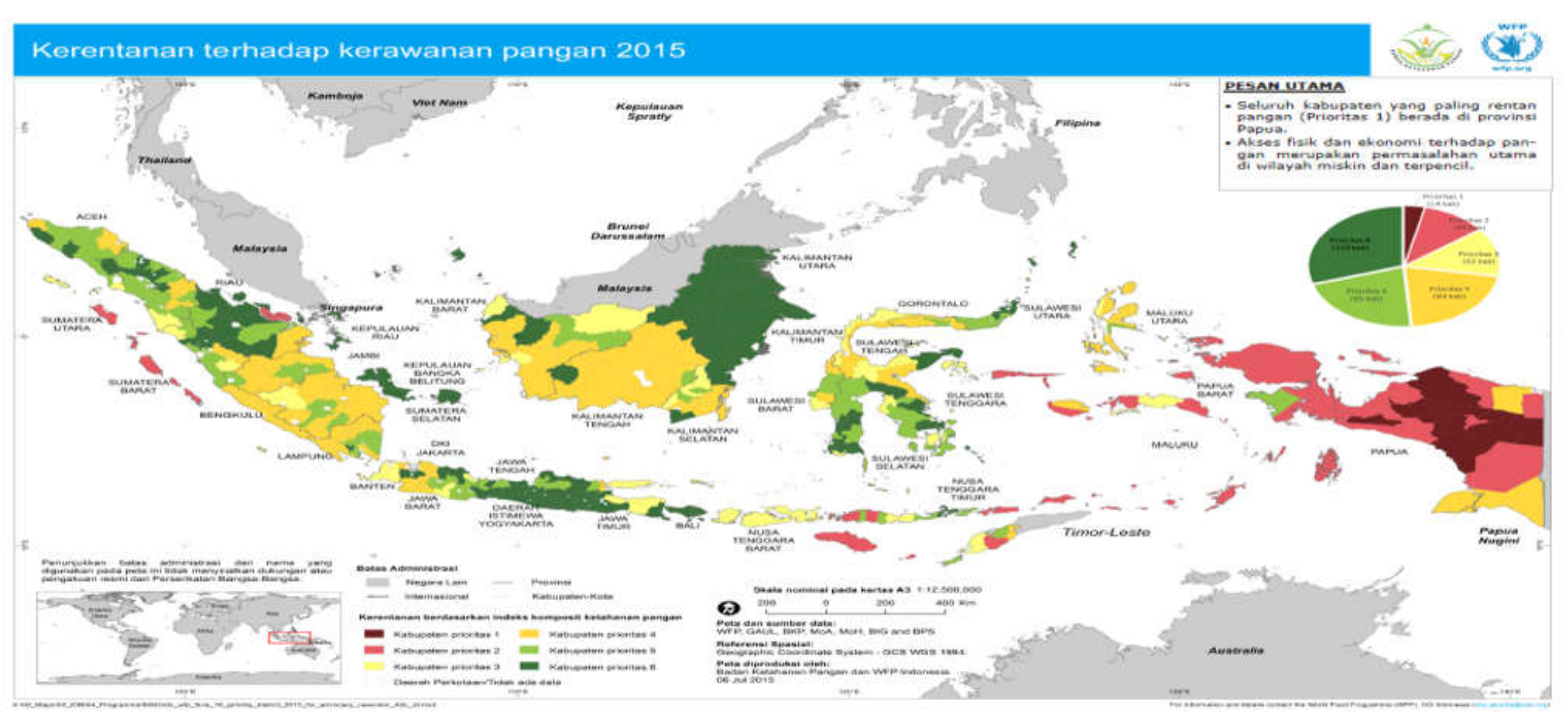

Figure 4. Food Security and Vulnerable Atlas Indonesia 2015

Source: WFP (2015)

Food security is not an end goal as it is a pathway to securing nutritional outcomes such as health and productivity. Outcome of malnutrition such as morbidity and mortality is directly linked to under nutrition for protein and energy which subsequently imply a long term effect consist of declining intellectual ability, falling economic productivity, degenerating of reproductive performance and increasing prevalence of disease-related malnutrition (DRM) and Non-communicable disease (NCD) (Lenoir-Wijnkoop, Jones, Uauy, Segal, \& Milner, 2013). However, many studies found that good nutrition depends not only on household's food intake but also adequate health environment and adequate maternal and child care; and finally the interaction between those three factors (Ruel et al, 1999; Blau et al, 1996; Iram and Butt, 2004; Tiwari, Skoufias, \& Sherpa 2013).

Food and nutrition security is determined by many variables. Studies found that socioeconomic and demographic factors mainly contribute to this achievement. Various factors drive food consumption decisions, not only economic factors such as income, and price of food, but also other socio-cultural factors including taste, lifestyle, and other complex variables such as knowledge, and burden in the family; leading to changes in household's food provision (Butt, 2004; Lestari, et al, 2015). Moreover, globalization has brought about a massive change in various livelihood aspects, including food trade policies which allows imported and manufactured food available across the regions and finally changes preference for food ${ }^{1}$. Tanziha (2016) showed that economic and social factors drive changes for food pattern. Economic drivers mainly due to urbanization, income and market liberalization while the socials driver are changes role for women and prestige. Changing role of housewife finally affect the quality of food provision where a mother tends to provide processed-unhealthy foods (convenience food) which are easily to cook, quickly served, and cheaper with high durability.

\section{Food and Nutrition Status for Indonesia}

World Food Programmed (2015) reported that Indonesia has been improving in food security status for the last decade, indicated by declining number of provinces with Priority 1 and 2 . The result is mainly contributed by improvement on the availability side, since the government emphasized interventions on food supplies.

Figure 4 shows that mainly provinces in Eastern part of Indonesia consist of East Nusa Tenggara, Maluku and Papua categorized as highly vulnerable districts classified as

\footnotetext{
${ }^{1}$ Several studies show that household preference on food has been changing towards convenience foods; irrespective to economic status and geographical disperse (Smeru, 2015 and Lestari, et al, 2015).
} 


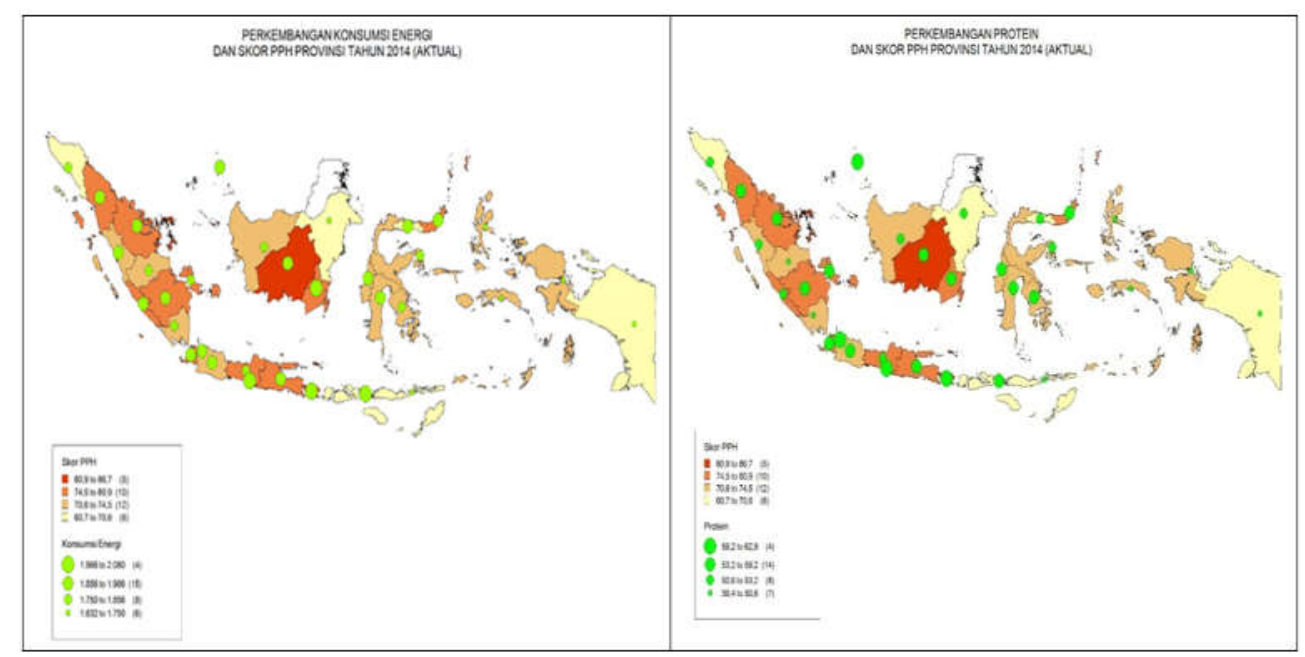

Figure 5. Dietary Diversity Score, Energy and Protein Intake Map (2014)

Source: BPS (2014) and Badan Ketahanan Pangan (2014)

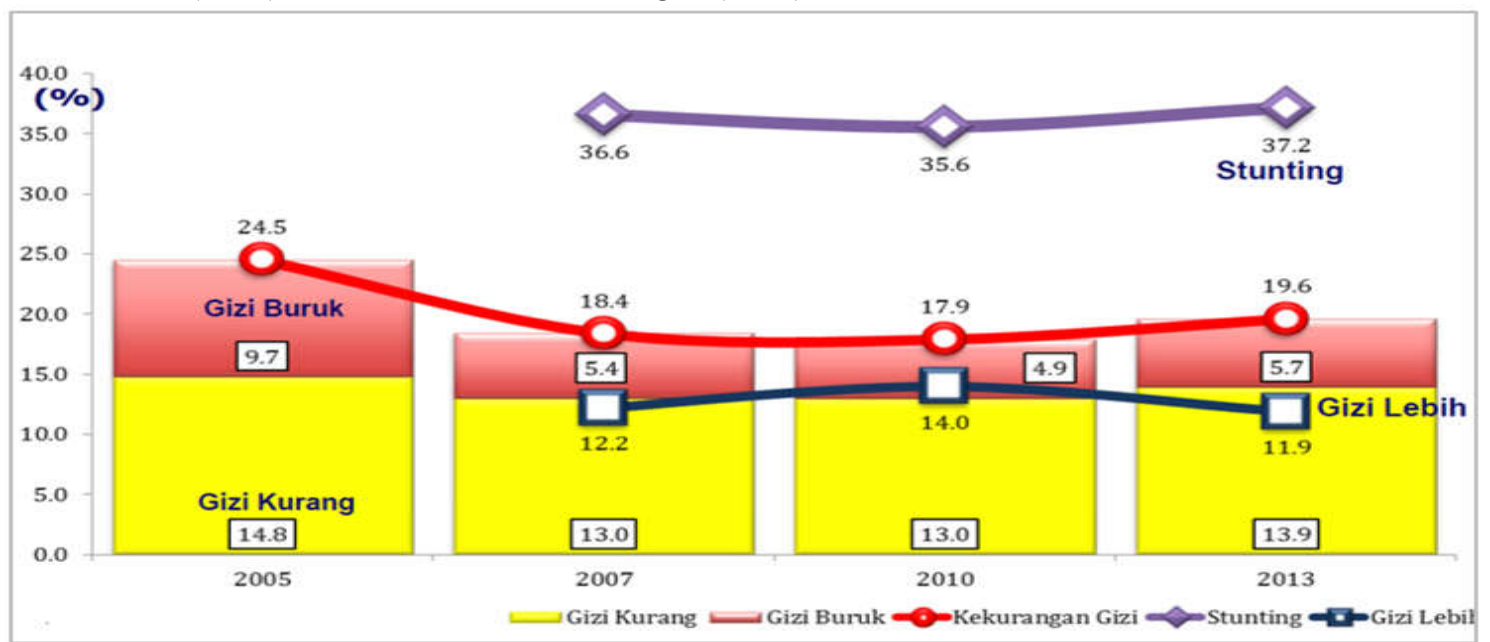

Figure 6. Nutrition Status of Children Under 5 Years Old

Source: Ministry of Health (2014)

Priority 1 and 2 which requires improvement in economic access of food, prevention and reduction of malnutrition and addressing issues of climate change (WFP, 2015).

However, this achievement needs to be reviewed on the micro perspective, by considering other measures especially the nutritional status and food consumption pattern. According to energy and protein intake, several provinces showed adequacy of nutrition intake. As for energy adequacy, almost provinces in Indonesia experienced lack of energy consumption with average of $1800 \mathrm{kkal}$, compare to the suggested intake of 2,200kkal/person/day. In contrast, protein intake varies among provinces. Several provinces like DKI Jakarta, Bali and Jogjakarta lead the way on the consumption of energy as well as protein which are above
$53 \mathrm{gr} /$ day compared to Papua with only just above half of protein intake of Jakarta (39 gr) (Figure 5).

One measure to examine the quality of individual dietary intake is diversity dietary intake (known as Pola Pangan harapan/PPH). Of 34 provinces in Indonesia, Jogjakarta has the highest score of $\mathrm{PPH}$, accounts for 86.7, followed by Bali (82.8). In contrast, East Nusa Tenggara experience the lowest PPH of 60.7 in 2014. To sum up, inadequate energy and protein intake lead to lower performance of quality diet ad finally prone to malnutrition.

As the results, child malnutrition in Indonesia is still very high. Ministry of Health (2013) recorded than stunting tend to increase between since 2007, indicating a crucial problems on food and lifestyle. 


\section{METHODOLOGY}

There are many measures used as the indicators of food security depends on the context and purpose of the analysis as well as tradeoffs between comprehensiveness and the ease and cost of data collection (Tiwari, Skoufias, \& Sherpa, 2013). For example, the FAO uses national level food balance sheets to come up with global undernourishment or hunger figures while the World Bank, as its focus on poverty, referring households below food poverty line as food insecure. Meanwhile, in order to address chronic hunger and malnutrition, a more detailed data collection at the household or individual level is required. Variations of population, culture, climate, agriculture, and food traditions and preferences to which any particular food security measure will have to be sensitive (Ruel, 2002). Because different indicators provide contrasting and sometimes contradictory results of food security, the decision about which indicators to use may impact policy decisions about food security interventions (Barrett, 2010, Tiwari, Skoufias, \& Sherpa, 2013).

Tiwari, Skoufias, \& Sherpa, (2013) linked and correlated the measures of household's food security with the nutritional status of children from many indicators, based on at least one of the pillars of food security: availability, access, utilization, or stability. The indicators consist of per capita expenditure; share of food in total expenditure; per capita caloric availability; food consumption score (FCS); household dietary diversity score (HDDS); mother's dietary diversity score (MDDS); child dietary diversity score (CDDS); household food insecurity access scale (HFIAS); starchy staple ratio (SSR); and share of food expenditure on starchy staples (SSEXR) for five different countries in South Asia and Africa. They rank all the indicators subject to two categories namely nutritional relevance rank and time and cost effectiveness. They found that among all the indicators, food consumption score (FCS) and household's diversity score (HDDS) are the most nutritional relevance indicators as well as having time and cost effectiveness.

However, calorie adequacy apparently the most common indicators used many studies (eg. Butt, 2004 and Tiwari, S., Skoufias, E., Sherpa, M., 2013) since it is mainly concerns of policy makers to address issues of transitory food security caused by drought or political upheaval. This measure captures food sufficiency in terms of quantity but does not address the quality of the diet. According to Butt (2004) there are two different measures could be also used to capture the quantity and quality of household food availability: (1) per capita calories intake per day and (2) price per 1,000 calories per person each day (kcal/aeu/day).

This study employs the first measure namely per capita calories intake as the dependent variable, which is the function of expenditures, household demographics, and non- food inputs. The equations for food availability are:

Log of calories per person or Price per 1,000 $\mathrm{kcal} / \mathrm{aeu} / /$ day $=\mathrm{g}$

Where $g=$ predicted household expenditure; household structure; mother's age; mother's education, water and sanitation; and dependency ratio.

The data is gathered from SUSENAS 2013, which have converted household food consumption into calorie that allow this study easier. As for household's calorie intake, SUSENAS module for food expenditure provide the data, and also other independent variables available from SUSENAS core. This study covers over 65,000 households. The model specification follows study of Butt (2004):

$L P C C A L=\beta_{0}+\beta_{1}($ LHINCM $)+\beta_{2}(L M A G E)+\beta_{3}(L M E D U)+\beta_{4}($ APWATR $)+$ $\beta_{5}(N T O L L T)+\beta_{6}(L D R)$

Where:

LPCCAL = log of percapita intake

LHINCM = Log of household annual income

LMEDU = Log mother's education (years of schooling)

LMAGE = Log of mother's age (years)

APWATR = Availability of piped water at house

NTOILT = Dummy of toilet facilities

LDR $\quad=$ Log of dependency ratio 
Table 2. Summary Statistics

\begin{tabular}{|ll|r|r|l|}
\hline Variables & Mean & $\begin{array}{l}\text { Standard- } \\
\text { Deviation }\end{array}$ & $\mathbf{N}$ & \multicolumn{1}{|c|}{ Definition } \\
\hline $\begin{array}{l}\text { Percapita calorie } \\
\text { intake }\end{array}$ & 58,896 & 17,746 & 70842 & $\begin{array}{l}\text { Household food consumption divided by the } \\
\text { number if household members }\end{array}$ \\
\hline Mother age & 43.72 & 13.32 & 66,213 & Age in years \\
\hline Mother education & 7.2 & 4.2 & 65,762 & Years of formal schooling \\
\hline Household & 13.3 & 0.69 & 70,842 & Rp (Annual) \\
\hline income & & & & \\
\hline Dependency ratio & 2.4 & 1.5 & 70,842 & $\#$ \\
\hline Toilet facility & 0.67 & 0.47 & 70,842 & $\begin{array}{l}\text { No toilet: 1 } \\
\text { Otherwise: 0 }\end{array}$ \\
\hline $\begin{array}{l}\text { Access to piped } \\
\text { water }\end{array}$ & 0.45 & 0.49 & 70,842 & $\begin{array}{l}\text { Piped water: 1 } \\
\text { Otherwise: 0 }\end{array}$ \\
\hline
\end{tabular}

Table 3. Estimation Results

\begin{tabular}{|l|r|r|}
\hline \multicolumn{1}{|c|}{ Variables } & \multicolumn{1}{c|}{ Coefficient } & \multicolumn{1}{c|}{ t-stat } \\
\hline Constant & -120851.6 & $-92.70^{*}$ \\
\hline Log of mother's age & 94.10 & $19.67^{*}$ \\
\hline Log of mother's education & -451.99 & $-26.60^{*}$ \\
\hline Toilet facility & -2778.63 & $-21.07^{*}$ \\
\hline Access to safe water & -3913.17 & $-30.64^{*}$ \\
\hline Log of households income & 13986.31 & $137.15^{*}$ \\
\hline Log of dependency ration & -1346.22 & $-34.05^{*}$ \\
\hline R2 & 0.27 & \\
\hline$F$-stat & 4092 & \\
\hline$N$ & 65.762 & \\
\hline Note: * significant at 1 percent & & \\
\hline
\end{tabular}

Source: SUSENAS 2013

\section{RESULTS AND DISCUSSION}

Calorie intake per capita is used as the proxy of food security while the explanatory variables are split into socio-economic variables, maternal variables and household's characteristics. Maternal characteristics in specific age and education are important since mother is the household's member responsible for food provision. Moreover, according to Butt (2004) mother's age and education represent maternal characteristics to capture phenotype (visible characteristics of individual produced by interaction of genes and environment) and genotype (individual's genetic composition) endowments. Maternal education is a proxy for maternal endowments. Meanwhile, mother's age accounts for the fact that very young mothers tend to have smaller experience than their high counterparts. Household's structured characteristics include household size as the proxy of dependency ratio. Socio-economic variables include the availability of safe drinking water and sanitation facility within the household.

Ordinary least square (OLS) regression was employed to estimate the determinants of household's food security. Table 2 reports the descriptive statistics of socio-economic and environmental variables employed in this analysis.

The main findings of the empirical analysis, as shown in Table 3 . In line with Butt (2004) mother's age has a positive and significant influence on per capita calorie 
intake at the household level, because mother's age enhances experience regarding provision of proper and required food for the family. However, the solitary impact of maternal education appeared to have a declining impact on average calorie intake within the sampled households, indicating that along with better education mother tend to participate in the labor force and subsequently have lesser time to provide food for the family. This finding is strengthen Tanziha (2015) who showed that education may increase the chance for mother to work and finally lead to adverse impact on calorie intake within the family. Moreover, education may not be related to healthy food knowledge and practices as educated people may not practicing healthy food consumption and vice versa. Food habit may have more influence than education.

A series of socio-demographic factors that may influence household food insecurity has been included in the regression analysis. Income is one of the primary causal factors used to explain household food security. Household income is a good predictor of household calorie adequacy. Average calorie availability appears to be higher in relatively high-income families. Present evidence shows that household income has a strong and significant impact on household per capita calorie intake. This result may suggest that better-off households choose a more expensive calorie-food or may be able to afford more food for their family. This supports the fact that malnutrition especially stunting is also occurs amongst middle and higher income groups. Health outcomes are functions of both food intake and non-food inputs such as environmental hygiene, personal hygiene and access to safe water and quality of sanitation facilities. The coefficient of access to safe water shows positive and significant impact on per capita calorie intake. Safe drinking water plays an important, but indirect role, for good nutrition and then for health. However, the negative relationship indicates that lack of access to safe water since clean water is relatively expensive in Indonesia in some regions.

Similarly, the study shows that unavailability of toilet facility within household has a negative and significant impact on calorie intake. The reasons may be that poor sanitation or contaminated water could lead to disease such as acute diarrhea may be left over to maintain good health (Butt, 2004). For all reasons, higher food intake availability may not lead to improved health outcomes unless measures are taken to improve access to safe water and sanitation.

Dependency ratio is also an important contributor towards the household average calorie intake. In line with Butt (2004), dependency ratio indicates strong and negative effect on per capita calorie intake within the sampled households. It is clear that high dependency ratio reduces the household per capita calorie intake because there are many persons in the household to share a plate of food. Also because a dependent person's contribution in earnings is zero and they do not participate in any economic activity for their family, but their share is fixed in household consumptions. So this situation may deteriorate the household food security through per capita calorie intake.

\section{CONCLUSION}

This study attempted to incorporate food and non-food factors that affect household's food consumption that reflected quantity and quality aspects in Indonesia. The indicator is reflected in calorie intake per capita as the function of several variables consists of socio-economic, maternal characteristics and non-food infrastructures that directly and indirectly determine quality of food absorption. The variables are income, size of family, mother's age and education, and dummy of water sanitation infrastructures such toilet facility and source of drinking waters. Data employed in this study gathered from SUSENAS 2013 covered for over 65,000 households in Indonesia.

The study showed that in Indonesia, socio-economic factors determine quality of food consumption which subsequently representing food and nutrition security in household level. Income positively affect calorie intake, indicating that higher income would increase quality of food consumption. However, recalling that calorie intake is measured as an aggregate 
of the total consumption regardless the each components contribute to the total intake- as measured in dietary diversity score- therefore the indicator and its relation to income may lead to ambiguity that higher income would lead to better food pattern. However, as for Indonesia income is not always associated with better or healthier food consumption as unhealthy diet intake takes place regardless the economic status. Even children from higher income families are vulnerable to over nutrition as well as those from poor families for under nutrition. This fact is also strengthen by this study that showed mother's education have adverse impact on calorie intake per capita, since even higher income groups with which the mother spend more years on schooling tend to dedicate the time for working and lesser quality of family's food provision. It apparently that higher education does not have linear correlation with knowledge on healthy food. Therefore, a more gendersensitive participatory analysis and evaluation of project interventions from a household food security and nutrition perspective and more targeted interventions to women.

In contrast, mother's age significantly affect calorie intake positively, indicating that more experience lead to better food provision. Meanwhile several variables may negatively affect calorie intake such as size of family as reflected in number of family member. Water and sanitation infrastructure positively affect calorie. However, it should be noted that availability of sanitation infrastructure such as availability of owned/public toilet is not ensure its use. Rural society, especially in remote areas still holds culture and perspective on toilet. For instance, provision of public toilet or private toilet supported by the local government in Madura or Aceh is not always effective to change community's behavior towards healthy daily practices. Local wisdom towards sanitation and behavior is one of the most difficult to change. Similarly, as this study support the fact that clean water especially for drinking is positively affect calorie intake and finally food and nutrition security, effort to broaden access towards healthy, affordable and accessible clean water urge to implement.
Based on this result, addressing food and nutrition security requires a comprehensive approach not only in terms of food quantity and quality, but also other inputs that contribute to the effectiveness of food consumption on health and environment supporting it. Apart from economic aspects which allow better quality of calorie intake, knowledge regarding on healthy food needs to be internalize for every level of groups, especially for mother. Formal education does not have a significant impact, indicates that knowledge needs various approach to be socialized. Access to water and sanitation should be enlarged as well as changes in mindset of communities, which could be use cultural approach.

\section{REFERENCES}

Badan Pusat Statistik. (2017). Persentase Pengeluaran Rata-rata per Kapita Sebulan Menurut Kelompok Barang Indonesia, 1999, 2002-2017,

Badan Pusat Statistik. 2017, Persentase Rumah Tangga menurut Provinsi dan Memiliki Akses terhadap Sanitasi Layak, 1993-2017, retrieved from https://www. bps.go.id/statictable/2016/01/25/1900/ persentase-rumah-tangga-menurutprovinsi-dan-memiliki-akses-terhadapsanitasi-layak-1993-2017.html.

Badan Ketahanan Pangan. (2017). Laporan Tahunan BKP 2017. Kementerian Pertanian, Jakarta.

Barrett, C. B. (2010). Measuring Food Insecurity, Science, 327 (5967): 825-828

Benson, T., (2008), Improving Nutrition as a Development Priority, Addressing Undernutrition in National Policy Processes.

Blau, D.M., Guilkey, D.K. and Popkin, B.M. (1996), Infant Health And The Labour Supply of Mothers, Journal of Human Resources, 31 (1), pp. 25-58.

Butt, U.I.M.S. (2004). Determinants of household food security. International Journal of Social economics, 31 (8), 753-766.

Centre for Alleviation of Poverty through Sustainable Agriculture (CAPSA). (2015). Food and Nutrition Security: Evolution of Concept and Way Forward. CAPSA Factsheet. 
FAO and European Union. (2013), Guidelines for measuring household and individual dietary diversity, retrieved from http:// www.fao.org/3/a-i1983e.pdf.

IFPRI, (2015), 2015 Global Hunger Index: Armed Conflict and The Challane of Hunger. Bonn, Washington, DC and Dublin, October.

Iram, U., \& Butt, MS. (2004). Determinants Of Household Food Security: An Empirical Analysis For Pakistan. International Journal of Social Economics, 31(8): $753-766$

Kementerian Pertanian. (2014b). Statistik Pertanian Tahun 2014. Jakarta, Indonesia.

Kementerian Pertanian. (2015a). Statistik Konsumsi Pangan Tahun 2015. Pusat data dan Sistem Informasi Pertanian, Sekretariat Jendral Kem. Pertanian, Jakarta.

Lenoir-Wijnkoop, I., Jones, P., Uauy, R., Segal, L., \& Milner, J. (2013). Nutrition Economics- Food as an Ally of Public Health". British Journal of Nutrition (109), 777-784.

Lestari, E. et al., 2015, Rekonstruksi Perilaku Konsumsi Menuju Ketahanan Sosial Ekonomi Masyarakat, Research Report (Unpublished), Economic Reserarch Center, Jakarta.

Ministry of Health, 2013. Statistik Kesehatan Dasar (Riskesdas 2013). Badan Litbang Kesehatan, Jakarta

Pieters, H., et. al., (2013). Conceptual Framework for the Analysis of Determinants of Food and Nutrition Security, FOODSECURE Working Paper No. 13, September, FOODSECURE.

Pinstrup-Anderson, P. (2000), Nutrition and development, IFPRI, prepared for the Novartis Symposium on Nutrition and Development, Basel, Switzerland, 30 November.

Retrieved from https://www.bps.go.id/ statictable/2009/06/15/937/persentasepengeluaran-rata-rata-per-kapitasebulan-menurut-kelompok-barangindonesia-1999-2002-2017.html.
Robertson, Aileen. (2003). Feeding and nutrition of infants and young children guidelines for the WHO European Region, WHO Regioal Publications, European Series No. 87, retrieved from file:///C:/Users/ESTA/Downloads/ FeedingandNutrition ofinfantsand youngchildren2000.pdf.

Ruel, M., Haddad, L. and Garrett, J. (1999). Some Urban Facts of Life: Implications for Food and Nutrition Policy, International Food Policy Research Institute, Washington DC.

Tanziha, I. (2016). Rawan Pangan dan Perubahan Pola Konsumsi Pangan. Paper Presented in internal FGD, Economic Research Center, 1 July 2016, Bogor.

Tiwari, S., Skoufias, E., Sherpa, M., (2013). Shorter, Cheaper, Quicker, Better: Linking Measures of Households Food Securities to Nutritional Outcomes in Bangladesh, Nepal, Pakistan, Uganda and Tanzania. Policy Reserach Working Paper WPS 6584, World Bank, August.

USDA. (1998). Food security assessment, GFA-10/December V3, Economic Research Service, Washington, DC.

Weingarner, L. (2000). The Concept of Food and Nutrition Security. International Training Course: Food and Nutrition Security Assessment Instruments and Intervention Strategies. Background Paper No. 1. Gtz, welt hunger hilfe and inwent.

World Food Program. (2015). Food Security and Vulnerability Atlas 2015. Dewan Ketahanan Pangan and WFP, Jakarta.

World Atlas. (2018). The Top Wheat Exporting and Importing Countries in the World. Retrieved from https://www.worldatlas. com/articles/the-top-wheat-exportingand-importing-countries-in-the-world. html, access in 21 December 2018. 